\title{
Hooking pattern, injury type and post-release survival of Genetically Improved Farmed Tilapia (GIFT) caught by circle and 'J'hooks in recreational fishing
}

\author{
PARAS NATH JHA, SALY N. THOMAS AND V. R. MADHU \\ ICAR-Central Institute of Fisheries Technology, Matsyapuri, Willingdon Island, Kochi - 682029, Kerala, India \\ e-mail: parasincof@gmail.com
}

\begin{abstract}
Recreational fishing by angling is practised worldwide which is gaining importance in India as well. Circle hooks are getting more popular as it shows less injury with enhanced post-release survival, which promote catch and release as well as conservation. In the present study, circle and ' $\mathrm{J}$ ' hooks were compared for hooking pattern, extent of injury and post-release survival in Genetically Improved Farmed Tilapia (GIFT) in recreational fishing. Results depicted that overall hooking rate was lower for circle hooks (29\%) than ' $J$ ' hooks (31\%). Occurrence of lip hooking was more with circle hooks (73.6\%) than ' $\mathrm{J}$ ' hooks (58.8\%), whereas jaw hooking was comparatively low in case of circle hooks than ' $\mathrm{J}$ ' hooks. Circle hooks showed no throat hooking whereas ' $\mathrm{J}$ ' hooks recorded $5.88 \%$ for the same. Foul hooking was not observed in case of both hook types. In the present study, with ' $J$ ' hooks, $52.9 \%$ of fishes showed no bleeding, slight and moderate bleeding was found in $17.6 \%$ fishes, whereas $11.7 \%$ had severe bleeding. For circle hooks, the corresponding values were 73.6, 21.05, 5.26 and $0 \%$. There was $100 \%$ survival for the fishes upto $72 \mathrm{~h}$ post-release in both cases.
\end{abstract}

Keywords: Circle hook, Hooking pattern, 'J' hook, Recreational fisheries, Tilapia

Recreational fishing is one of the most sought after activity associated with tourism and is a booming business worldwide. Recreational fishing is gaining importance in different states of India like Kerala, Assam, Arunachal Pradesh, Nagaland, Himachal Pradesh, Karnataka and West Bengal (Harikumar and Rajendran, 2007; Gupta et al., 2015a, b; 2016; Baruah et al., 2017; Baruah, 2018; Baruah and Sarma, 2018; Mandal et al., 2018).

Fishing hooks are the simplest and the most important gear as far as selectivity, ease of operation and cost effectiveness are concerned (Saly et al., 2007). Shape, size and design of hooks have a large influence on target species and catching efficiency. Similarly, physical and mechanical properties of hooks and behaviour of target species also affect catching efficiency (Lokkeborg and Bjordal, 1992), whereas efficacy depends upon spear angle of hook and direction of the pull in lines (Baranov, 1976). On the basis of shape and orientation, hooks are of two types, 'J' hook and circle hook. In ' $\mathrm{J}$ ' hooks point of barb is parallel to the shank while in circle hooks point is turned inwards, towards the shank of the hook (Serafy et al., 2012; Gilman et al., 2016). 'J' hooks are reported to cause deep hooking and more injury whereas circle hooks show lip or jaw hooking and minor injury to the fish (Huse and Ferno, 1990). Reports have shown that the probability of deep hooking (hooking in throat/gut) is comparatively low in circle hook due to its design characteristics (Grover et al., 2002; Kerstetter and Graves, 2006; Pacheco et al., 2011). In recreational fishing, the practice of catchand-release is becoming obligatory and this would be a norm in the future (Beckwith and Rand, 2005) and anglers are adopting different methods to promote conservation in recreational fishing. Fish caught with circle hooks are found to have better survival when released and is gaining importance as an effective design in recreational fisheries (Minami et al., 2006; Grixti et al., 2010). The use of circle hooks in angling is very rare in the Indian angling sector (Gopal and Saly, 2012; Saly, 2012) and only a few studies have been carried out on the efficacy of circle hooks (Edappazham, 2009; Kumar et al., 2013). In recreational fishing, handling time and physical injury/stress play a major role in survival of hooked fish. In this context, a study was undertaken to compare hooking pattern, injury and post-release survival in Genetically Improved Farmed Tilapia (GIFT) from recreational fish farms, caught by ' $J$ ' and circle hooks.

Experiments were conducted at two recreational fish farms, viz., Matsyafed Fish Farm and Green Aqua Fish Farm, Narakal, Ernakulam District in Kerala, India. A total of 116 angling operations were carried out with fishing rods using circle and ' $\mathrm{J}$ ' hooks alternately. Two barbed hooks viz., circle hook of 1/0 size (Mustad) and straight shank J-hook of no.19/0 size (Mustad) baited with shrimp (Metapenaeus dobsoni, size range: $2.5-4 \mathrm{~cm}$ ) were cast 
alternately. Each shrimp was cut in to small bait pieces, considering the fact that the mouth opening of tilapia is small. Although brand sizes of the two hooks were different, the overall dimensions were similar. A single hook was rigged at the terminal end of a polyamide (nylon) monofilament line of $0.22 \mathrm{~mm}$ diameter. Operational conditions during the experiments were kept identical to avoid influence of operational parameters on the results. One casting was considered as one attempt. A strike or fish bite, which resulted in pulling the line out of the water, was considered as one bite. After each bite, the deployed hook was taken out of water with a jerk which resulted either in catch or nil catch. Hooking locations were categorised as lip hooked, jaw hooked, throat hooked, gut hooked and foul hooked. The severity of bleeding was classified based on visual observation of the captured fish. Four point grade scales from 0 to 3 was used. Based on the extent of bleeding, a score of 0 (no bleeding), 1 (slight bleeding), 2 (medium bleeding) and 3 (severe bleeding) was given as per Rapp et al. (2008). Catch per unit effort (CPUE) was calculated as weight of live fish caught per hour spent by the angler. Hooking rate was expressed as the ratio of number of successful hooking divided by the number of hooks deployed (Prince et al., 2002). Captured fish was immediately taken out of water and parameters such as hooking locations and extent of bleeding were recorded. After recording the data, fish were immediately tagged and released to floating cages of dimensions $1 \times 0.6$ x $0.6 \mathrm{~m}$, placed in the same farm. Incidence of short-term mortality if any was monitored for $72 \mathrm{~h}$.

The total catch landed was $8.04 \mathrm{~kg}(\mathrm{n}=35)$. Average weight and length of fish recorded were $223.3 \pm 2.4 \mathrm{~g}$ and $21.7 \pm 0.5 \mathrm{~cm}$ respectively. No significant differences were noticed in the length $(\mathrm{t}=0.387$, df $=32$, S.E $=1.015$,

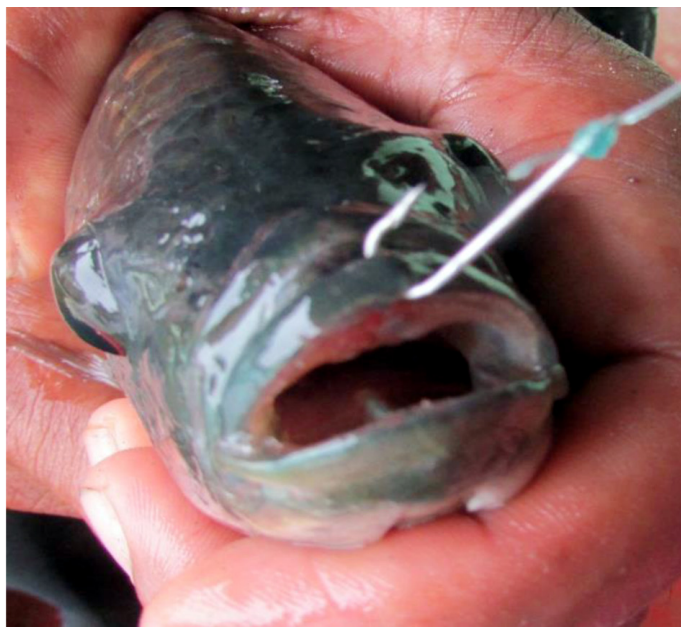

(a)

Fig. 1. (a) Lip hooking and (b) throat hooking in tilapia $\mathrm{p}>0.05)$ or weight $(\mathrm{t}=0.271, \mathrm{df}=32$, s.e. $=25.32, \mathrm{p}>0.05)$ of the fishes caught by the two types of hooks. Average time between setting of hook and capture was $1.69 \pm 0.66$ min, whereas average time between capture and release back to cage was recorded as $5.25 \pm 0.32 \mathrm{~min}$. In the present study, circle hooks had a lower hooking rate $(29 \%)$ than ' $\mathrm{J}$ ' hooks (31\%). Out of the 58 deployments of each type of hook, circle hook caught 17 fishes and ' $\mathrm{J}$ ' hook caught 18 fishes. Prince et al. (2002) reported that circle hooks had 1.83 times higher hooking rate compared to ' $\mathrm{J}$ ' hooks for sailfish. CPUE (in terms of live weight) for the circle hooks was $1.82 \mathrm{~kg} \mathrm{~h}^{-1}$ while it was $1.44 \mathrm{~kg} \mathrm{~h}^{-1}$ for 'J'hooks. Falterman and Graves (2002) also reported higher CPUE for circle hooks, in longline fishery of yellowfin tuna.

Of the total fishes hooked, 66.6, 30.5 and $2.7 \%$ were hooked at lip, jaw and throat respectively (Fig. 1). With 'J' hooks, maximum fish (58.8\%) were hooked at lip, $35.2 \%$ were hooked at jaw and $5.88 \%$ at throat. In the case of circle hooks, 73.6 and $26.3 \%$ fishes caught were hooked at lip and jaw respectively. (Fig. 2). The incidence of lip hooking was more in the case of circle hook than in ' $\mathrm{J}$ ' hook, whereas jaw hooking was comparatively low in case of circle hook than ' $\mathrm{J}$ ' hook. Maximum jaw and lip hooking were recorded in circle hook which helped in increased post-release survival rate due to minimum injury (Kumar et al., 2013). Efficiency of circle hooks in hooking by jaw region is widely reported (Huse and Ferno, 1990; Cooke and Suski, 2004). Yokota et al. (2006) and Curran and Bigelow (2011), reported no throat hooking and deep hooking while using circle hook. In the present study, circle hook showed no throat hooking whereas ' $\mathrm{J}$ ' hook accounted for $5.88 \%$ of the same. One of the reasons of higher rate of incidence of jaw hooking with circle hooks is its tendency to slip over soft tissues and getting rotated

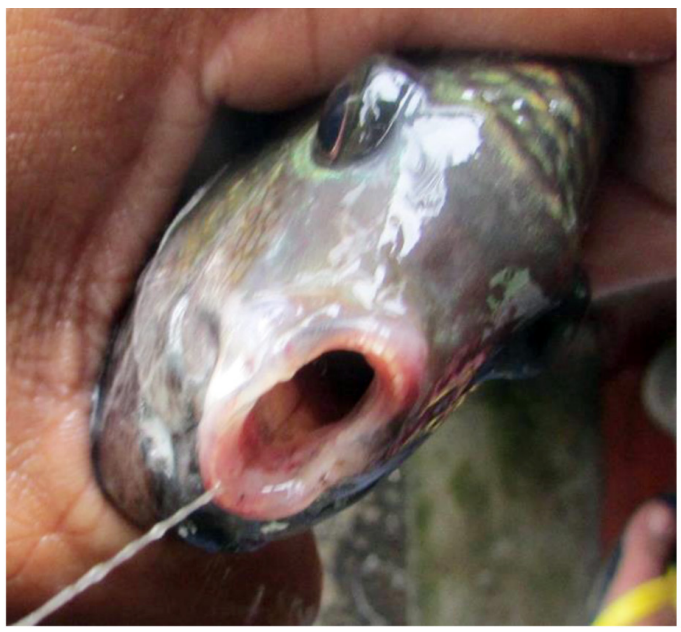

(b) 


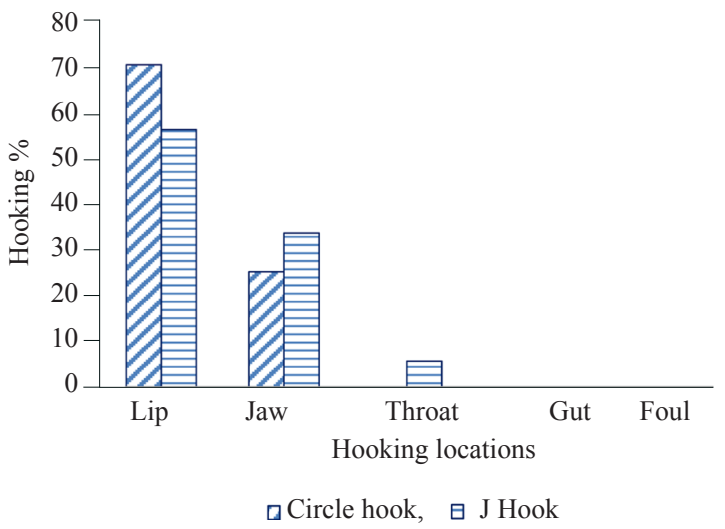

Fig. 2. Hooking location in tilapia caught by different hook types

resulting in jaw hooking (Cooke and Suski, 2004). Aalbers et al. (2004) reported hooking in delicate areas such as stomach, oesophagus and gills leading to post-release mortality than those hooking in non-critical areas. Several studies indicated that circle hooks can produce higher catch rates than traditional 'J' hooks (Yokota et al., 2006; Kerstetter and Graves, 2006; Kerstetter et al., 2007; Ward et al., 2009; Swimmer et al., 2011). Studies conducted by Yokota et al. (2006) and Pacheco et al. (2011) showed that changes in hook pattern have little effect on the catch composition. For both hook designs, hooking at gut and tail were not observed. In the present study, thus, no deep hooking was observed in either ' $\mathrm{J}$ ' or circle hooks which could be attributed to the small mouth opening of tilapia.

The observation on bleeding occurrence and severity revealed that of the total fishes captured, $63.8 \%$ did not show bleeding. Slight, moderate and severe bleeding were recorded in 19.4, 11.1 and 5.5\% fishes caught respectively. In case of ' $\mathrm{J}$ ' hooks, $52.9 \%$ of fishes showed no bleeding, $17.6 \%$ each showed slight and moderate bleeding, whereas $11.7 \%$ had severe bleeding. For circle hooks, the corresponding values were $73.6 \%$ (no bleeding), $21.05 \%$ (slight bleeding), 5.26\% (moderate bleeding) and $0 \%$ (severe bleeding) (Fig. 3). In circle hook, severe bleeding was not recorded in any of the fish caught. Edappazham and Saly (2016) reported $66.67 \%$ incidence of minor injuries in fish caught with circle hooks, while $22.22 \%$ of fish suffered moderate injuries and only $11.11 \%$ showed severe injuries, whereas $21.43 \%$ of fish caught using the conventional J-hook had minor injuries, $35.71 \%$ had moderate injuries and $42.86 \%$ showed severe wounds. One of the reasons for low injury recorded with circle hooks could be their design, which leads the hook to move to the corner of the fish's mouth as the fish swims away (Anon., 2005).

There was $100 \%$ survival for the fishes up to $72 \mathrm{~h}$ post-release in both cases. In view of the fact that circle

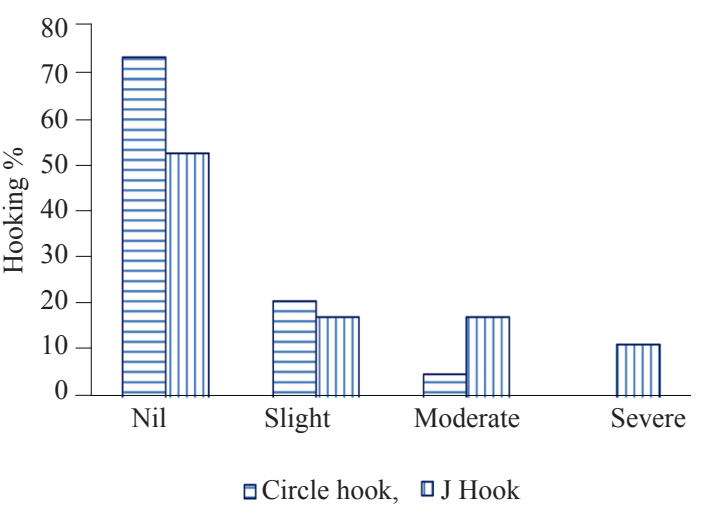

Fig. 3. Extent of bleeding/injury in tilapia caught in different hook types

hook causes minimum injury to the fish, post-release survival is enhanced (Bacheler and Buckel, 2004; Watson et al., 2005; Gilman et al., 2006; Kerstetter et al., 2007; Read, 2007; Pacheco et al., 2011; Swimmer et al., 2011). Lukacovic (1999) reported post-release mortality rate of 9.1 and $0.8 \%$ for fishes caught on conventional hooks and circle hooks respectively. Findings of Cooke et al. (2003) revealed that post-release mortality was significantly lower in circle hooks as against J-hooks in striped bass. In the present study, no mortality was observed upto $72 \mathrm{~h}$ of observation. This could be due to the low physical injury coupled with less handling time and the sturdy nature of the experimental fish used.

The results of the present study showed that the circle hooks were better than ' $\mathrm{J}$ ' hooks with respect to lower injury due to hooking location. Though the post-release survival was assessed only for $72 \mathrm{~h}$, based on the injury pattern observed in hooked fishes, it can be assumed that the survival of fishes released from circle hooks would be higher than that from J hooks. Further studies using target fishes for recreational fishing and long term monitoring of the released/escaped fish for survival estimations, would be required for corroborating the findings.

\section{Acknowledgements}

Authors are grateful to the Director, ICAR-CIFT, Kochi, for providing necessary facilities for carrying out this work and permission accorded to publish this paper. Authors also would like to acknowledge Mr. P. N. Nikhil Das for the help rendered during field trials.

\section{References}

Aalbers, S. A., Stutzer, G. M. and Drawbridge, M. A. 2004. The effect of catch-and-release angling on the growth and survival of juvenile white seabass captured on offset circle and J-type hooks. North Am. J. Fish. Manag., 24: 793-800. DOI: 10.1577/M03-034.1. 
Anon. 2005. Mustad gives turtle friendly hooks to WWF. http:// www.mustad.no/misc_news_turtles.html, (Accessed 20 February 2019).

Bacheler, N. M. and Buckel, J. A. 2004. Does hook type influence the catch rate, size and injury of grouper in a North Carolina commercial fishery. Fish. Res., 69: 303-311. doi:10.1016/j. fishres.2004.07.001.

Baranov, F. I. 1976. Commercial fishing technique. In: Vilim, E. (Ed.), Selected works on fishing gear vol. I. Translated from Russian (by P. Greenberg), Israel Programme for Scientific Translations, Jerusalem. Keter Publishing House Ltd., Jerusalem, Israel, 631 pp.

Baruah, D. 2018. Scope of recreational fisheries in North-east India. Aquac. Asia, 38(1\&2): 93-100.

Baruah, D. and Sarma, D. 2018. Mahseer in recreational fisheries and ecotourism in India. Aquac. Asia, 22(2): 3-10.

Baruah, D., Kunal, K., Sarma, D., Singh, A. K., Kamut, K. and Thungon, P. K. 2017. Trout fisheries in the uplands of Arunachal Pradesh: Resources and opportunities. Aquac. Asia, 22(3): 3-11.

Beckwith, Jr. G. H. and Rand, P. S. 2005. Large circle hooks and short leaders with fixed weights reduce incidence of deep hooking in angled adult red drum. Fish. Res., 71: 115-120.

Cooke, S. J., Suski, C. D., Barthel, B. L., Ostrand, K. G., Tufts, B. L. and Philipp, D. P. 2003. Injury and mortality induced by four hook types on bluegill and pumpkin seed. N. Am. J. Fish. Manage. 23: 883-893.

Cooke, S. J. and Suski, C. D. 2004. Are circle hooks an effective tool for conserving marine and freshwater recreational catch-and-release fisheries? Aquat. Conserv. Mar. Freshw. Ecosyst., 14: 299-326. DOI: 10.1002/aqc.614.

Curran, D. and Bigelow, K. 2011. Effect of circle hooks on pelagic catches in the Hawaii-based tuna longline fishery. Fish. Res., 109: 265-275. DOI: 10.1016/j.fishres.2011.02.013.

Edappazham, G. 2009. Performance evaluation of commercially important Indian and imported fishing hooks, Ph. D. Thesis, Cochin University of Science and Technology, Kochi, Kerala, India.

Edappazham, G. and Saly N. Thomas. 2016. Influence of hook types on hooking rate, hooking location and severity of hooking injury in experimental handline fishing in Kerala. Fish. Technol., 53: 284-289.

Falterman, B. and Graves, J. E. 2002. A preliminary comparison of the relative mortality and hooking efficiency of circle and straight shank ("J") hooks used in the pelagic longline industry. American Fisheries Society Symposium, 30: 80-87.

Gilman, E., Chaloupka, M., Swimmer, Y. and Piovano, S. 2016. A cross-taxa assessment of pelagic longline bycatch mitigation measures: Conflicts and mutual benefits to elasmobranchs. Fish Fish., 17(3): 748-784.
Gilman, E., Zollet, E., Beverly, S., Nakano, H., Davis, K., Shiode, D., Dalzell, P. and Kinan, I. 2006. Reducing sea turtle bycatch in pelagic longline fisheries. Fish. Fish., 7: 2-23. https://doi.org/10.1111/j.1467-2979.2006.00196.x.

Gopal, T. K. S. and Saly N. Thomas. 2012. Recreational fishing in India: prospects and management. In: Pandey, N. N., Patiyal, R. S., Shahi, N. and Akhtar, M. S. (Eds.), Mountain fisheries: Souvenir-cum-Abstract Book, National Seminar on Challenges and opportunity for livelihood security, 5-6 November 2012, Directorate of Coldwater Fisheries Research, Bhimtal, Uttarakhand, India, p. 43-46.

Grixti, D., Conron, D. S., Ryan, K. and Versace, V. L. 2010. Circle versus longshank hooks: comparing hooking locations and recreational catch for juveniles of snapper Pagrus auratus and King George whiting Sillaginodes punctatus. Fish. Res., 106: 27-31.

Grover, A. M., Mohr, M. S. and Palmer-Zwahlen, M. L. 2002. Hook-and-release mortality of Chinook salmon from drift mooching with circle hooks: management implications for California's ocean sport fishery. In: Jon A. Lucy (Ed.), National Symposium on Catch and release in marine recreational fisheries, American Fisheries Society Symposium 30, 5-8 December 1999, Virginia Beach, USA, p. 39-56.

Gupta, N., Bower, S. D., Raghavan, R., Danylchuk, A. J. and Cooke, S. J. 2015a. Status of recreational fisheries in India: Development, issues and opportunities. Rev. Fish. Sci. Aquac., 23(3): 291-301.

Gupta, N., Raghavan, R., Sivakumar, K., Mathur, V. and Pinder, A. C. 2015b. Assessing recreational fisheries in an emerging economy: Knowledge, perceptions and attitudes of catchand-release anglers in India. Fish. Res., 165(2015): 79-84.

Gupta, N., Bower, S. D., Cooke, S. J., Danylchuk, A. J. and Raghavan, R. 2016. Practices and attitudes of Indian catch-and-release anglers: Identifying opportunities for advancing the management of recreational fisheries. J. Threat. Taxa, 8(4): 8659-8665.

Harikumar, G. and Rajendran, G. 2007. An overview of Kerala fisheries with particular emphasis on aquaculture. IFP Souvenier 2007, p. 1-19.

Huse, I. and Ferno, A. 1990. Fish behaviour studies as an aid to improved longline hook design. Fish. Res., 9: 287-297. https://doi.org/10.1016/0165-7836(90)90047-Y.

Kerstetter, D. W. and Graves, J. E. 2006. Effects of circle versus $\mathrm{J}$-style hooks on target and non-target species in a pelagic longline fishery. Fish. Res., 80(2-3): 239-250. DOI: 10.1016/j.fishres.2006.03.032.

Kerstetter, D. W., Pacheco, J. C., Hazin, F. H., Travassos, P. E. and Graves, J. E. 2007. Preliminary results of circle and J-style hook comparisons in the Brazilian pelagic longline fishery. SCRS/2006/150, Col. Vol. Sci. Pap. ICCAT, 60(60): 2140-2147.

Kumar, K. V. A., Khanolkar, P. S., Pravin, P., Madhu, V. R. and Meenakumari, B. 2013. Effect of hook design on longline catches in Lakshadweep Sea, India. Indian J. Fish., 60(1): 21-27. 
Lokkeborg, S. and Bjordal, A. 1992. Species and size selectivity in longline fishing: a review. Fish. Res., 13:311-322. doi: 10.1016/0165-7836(92)90084-7.

Lukacovic, R. 1999 .Hooking mortality of deep and shallowhooked striped bass under different environmental conditions in Chesapeake Bay. In: Weinrich, D. R., Piavis, P. G., Pyle, B. H., Jarzynski, A. A., Walstrum, J. C., Sadzinski, R. A., Webb, E. J., Rickabaugh, H. W., Zlokovitz, E., Mower, J. P., Lukacovic, R. and Whiteford, K. A. (Eds.), Stock Assessment of selected resident and migratory recreational finfish species within Maryland's Chesapeake Bay. Federal Aid Project F-54-R. Annual Report, Department of the Interior, Fish and Wildlife Service, U.S. Fish and Wildlife Service, USA, $252 \mathrm{pp}$.

Mandal, A., Das, S. K., Biswas, B. and Kairnar, S. O. 2018. Future scope of sport fisheries in India: a review. Indian $J$. Anim. Health, 57(1): 01-16.

Minami, H., Yokota, K. and Kiyota, M. 2006. Effect of circle hooks and feasibility of de-hooking devices to reduce incidental mortality of sea turtles in the Japanese longline fishery. Scientific Committee Second Regular Session, Western and Central Pacific Fisheries Commission [WCPFC-SC2-2006/EB WP-9], Kolonia, Federal States of Micronesia, 8 pp.

Pacheco, P. C., Kerstetter, D. W., Hazin, F. H., Hazin, H., Segundo, R. S. S. L., Graves, J. E., Carvalho, F. and Travassos, P. E. 2011. A comparison of circle hook and "J" hook performance in a western equatorial Atlantic ocean pelagic longline fishery. Fish. Res., 107: 39-45.

Prince, E. D., Ortiz, M. and Venizelos, A. 2002. A comparison of circle hook and "J" hook performance in recreational catch-and-release fisheries for billfish. American Fisheries Society Symposium, XX: 1-14.

Rapp, T., Cooke, S. J. and Arlinghaus, R. 2008. Exploitation of specialised fisheries resources: The importance of hook size in recreational angling for large common carp
(Cyprinus carpio L.). Fish. Res., 94: 79-83. DOI: 10.1016/j. fishres. 2008.06.019.

Read, A. 2007. Do circle hooks reduce the mortality of sea turtles in pelagic longlines? A review of recent experiments. Biol. Con., 135: 155-169. doi:10.1016/j.biocon.2006.10.030.

Saly N. Thomas, Edappazham, G., Meenakumari, B. and Ashraf, P. M. 2007. Fishing hooks: A review. Fish. Technol., 44 (1): $1-16$.

Saly N. Thomas 2012. Recreational fisheries and resource conservation. In: Saly N. Thomas, Leela Edwin, Pravin, P., Remesan, M. P., Ashraf, P. M., Baiju, M. V. and Madhu, V. R. (Eds.), Fish harvesting systems for resource conservation. ICAR-Central Institute of Fisheries Technology, Kochi, India, p. 273-278.

Serafy, J. E., Cooke, S. J., Diaz, G. A., Graves, J. E., Hall, M., Shivji, M. and Swimmer, Y. 2012. Circle hooks in commercial, recreational and artisanal fisheries: Research status and needs for improved conservation and management. Bull. Mar. Sci., 88(3):371-391.

Swimmer, Y., Suter, J., Arauz, R., Bigelow, K., Lopez, A., Zanela, I., Bolanos, A., Ballestero, J., Suarez, R., Wang, J. and Boggs, C. 2011. Sustainable fishing gear: the case of modified circle hooks in a Costa Rican longline fishery. Mar. Biol., 158: 757-767.

Ward, P., Epe, S., Kreutz, D., Lawrence, E., Robins, C. and Sands, A. 2009. The effect of circle hooks on bycatch and target catches in Australia's pelagic longline fishery. Fish. Res., 97: 253-262. DOI: 10.1016/j.fishres.2009.02.009.

Watson, J. W., Epperly, S. P., Shah, A. K. and Foster, D. G. 2005. Fishing methods to reduce sea turtle mortality associated with pelagic longlines. Can. J. Fish. Aquat. Sci., 62: 965-981. doi: 10.1139/F05-004.

Yokota, K., Kiyota, M. and Minami, H. 2006. Shark catch in a pelagic longline fishery: Comparison of circle and tuna hooks. Fish. Res., 81(2-3): 337-341. 